\title{
Analisis Faktor Konfirmatori Connor-Davidson Resilience Scale
}

\author{
Putri Nur Azizah, Herlina Siwi Widiana, Siti Urbayatun \\ Fakultas Psikologi, Universitas Ahmad Dahlan \\ email: herlina.widiana@psy.uad.ac.id
}

\begin{abstract}
Abstrak
Artikel INFO

Diterima:19 Oktober 2020 Direvisi :11 Des 2020

Disetujui: 29 Maret 2021

DOI:

http://dx.doi.org/

10.24014/jp.v14i2.11043

Resiliensi yang merupakan kapasitas individu dalam menghadapi peristiwa yang kurang menyenangkan sangatlah dibutuhkan dalam masa pandemi seperti saat ini. Alat ukur resiliensi yang valid sangat diperlukan untuk memperoleh data yang akurat tentang daya tahan individu menghadapi peristiwa yang tidak menyenangkan Tujuan dari penelitian ini adalah untuk menguji validitas konstruk dari skala Connor-Davidson Resilience Scale (CD-RISC) pada populasi orang dewasa awal. Dalam penelitian ini, peneliti menguji empat faktor resiliensi skala CD-RISC yaitu fleksibilitas untuk mengatasi perubahan dan tantangan, dukungan dari keluarga dan lingkungan sosial, pengaruh spiritual dan memiliki kehidupan yang berorientasi pada tujuan. Seratus sembilan orang berusia antara 18 sampai dengan 40 tahun berpartisipasi menjadi sampel dalam penelitian ini. Pengumpulan data dilakukan secara online dengan mengisi google form. Metode analisis yang digunakan dalam penelitian ini adalah confirmatory factor analysis (CFA) dengan software AMOS 24. Berdasarkan analisis dengan metode CFA dapat disimpulkan bahwa struktur faktor pada model pengukuran skala CD-RISC fit. Skala CD-RISC valid untuk mengukur resiliensi pada orang dewasa awal.
\end{abstract}

Kata kunci: analisis factor konfirmatori, resiliensi, validitas konstruk.

\section{A confirmatory factor analysis of Connor-Davidson Resilience Scale}

\begin{abstract}
Resilience - an individual capacity in facing unpleasent events is needed in the pandemic era nowadays. A valid measurement tool to asses resilience is needed to gain acurate data on individual resilience toward unpleasent events. This study aimed yo test the construct validity of Connor-Davidson Resilience Scale (CD-RISC) among early adulthood. Four factors of resilience that are flexibilityto cope with change and challenges, support from family and social environment, spiritual influence and have a goal oriented life. One hundred and nine people age ranged from 18 to 40 years olds participated as sample of this study. Data were collected online with google form and then analysed with confirmatory factor analysis (CFA) with AMOS 24. . The results show measurement model of CD-RISC were fit with the data. Therefore CD-RISC is valid to measure resilience among early adulthood.
\end{abstract}

Keywords: confirmatory factor analysis, construct validity, resilience.

\section{Pendahuluan}

Perubahan dan peristiwa yang menimbulkan stres pasti dialami orang dewasa dalam kehidupan sehari-hari (Lesmana, 2008). Peristiwa kurang menyenangkan menumbuhkan suatu tantangan bagi manusia yang mungkin dirasakan mengganggu dalam kehidupan sehari-hari namun harus dijalani dan diselesaikan. Peristiwa kurang menyenangkan yang dapat menimpa individu antara lain yaitu kehilangan orang terdekat, adanya bencana alam yang tak terduga atau kecelakaan yang tidak diinginkan. 
Tantangan ini memicu kemampuan manusia untuk memiliki daya upaya yang tinggi, semangat dan keberanian dalam menghadapi tantangan serta kemauan untuk berubah. Individu menerapkan beberapa strategi yang berkaitan dengan perubahan yang dapat membantu mereka menyesuaikan diri dengan yang merugikan situasi. Salah satu strategi yaitu resiliensi yang merupakan salah satu kajian dalam psikologi positif (Hendriani, 2018)

Resiliensi adalah kemampuan individu untuk dapat beradaptasi menghadapi stres dan kemalangan. Resiliensi juga mengarahkan kemampuan seseorang mencapai keseimbangan dan kesehatan yang stabil dalam psikologis maupun fisik meskipun dalam kondisi menghadapi keadaan dengan tingkat stres yang tinggi dan kejadian traumatis (Meichenbaum, 2009). Pribadi yang resilien adalah pribadi dengan karakteristik memiliki cara yang baik dalam menyikapi stres, tetap dapat menjalankan dengan hasil yang baik meski di bawah tekanan, dapat bangkit dari trauma dan menggunakan tantangan sebagai alat untuk memacu diri menjadi lebih baik

Resiliensi mengarah pada penyesuaian yang positif saat menghadapi peristiwa yang kurang menyenangkan dan bagaimana cara seseorang untuk bangkit dari peristiwa tersebut. Resiliensi secara umum mengarah pada pola adaptasi positif selama atau sesudah menghadapi kesulitan atau resiko. Resiliensi adalah ide yang mengacu pada kapasitas sistem dinamis untuk bertahan atau pulih dari gangguan (Utami, 2017). Secara derivasi etimologis, kata resiliens berasal dari Bahasa Latin melunakkan, yang berarti memantul, melompat atau menghentak. Anteseden yang berulang kali ditemukan menjadi persyaratan untuk pembentukan resiliensi adalah kehadiran suatu peristiwa yang merugikan atau traumatis. Peristiwa ini dapat menempatkan individu pada risiko untuk mengorbankan kemampuan mereka untuk mengatasi dan mengatasi stresor (Garcia-Dia, 2013)
Manusia akan mengembangkan cara untuk mengubah keadaan yang penuh tekanan menjadi sebuah kesempatan untuk pengembangan diri pribadi. Meningkatkan resiliensi adalah tugas yang penting karena hal ini dapat memberikan pengalaman bagi manusia dalam menghadapi tantangan dan kesulitan hidup. Mengetahui resiliensi merupakan salah satu cara untuk mengidentifikasi individu yang beresiko mengalami depresi setelah mengalami peristiwa traumatik Individu yang memiliki resiliensi lebih memiliki potensi yang rendah untuk mengalami depresi setelah 12 bulan pasca peristiwa traumatis (Rainey, 2014)

Penelitian ini menguji skala resiliensi Connor-Davidson Resilience Scale (CDRISC) dengan modifikasi tiga item yang dilakukan oleh Dong dkk (2013). Penelitian sebelumnya menggunakan CD-RISC untuk mengukur resiliensi pada caregiver penderita thalasemia di Indonesia (Kurniawan, 2015). Berdasarkan hasil ujicoba pada penelitian sebelumnya aitem berjumlah 25 , dengan koefisien daya diskriminasi aitem bergerak dari 0,560 sampai dengan 0,905 dan reliabilitas yang tinggi (alpha $=0,975$ ).

CD-RISC disusun berdasarkan factorfaktor resiliensi, yaitu individu mampu mencerminkan gagasan kompetensi personal, standar yang tinggi dan memiliki keuletan; percaya pada orang lain dan mentolerir terhadap dampak negative; penerimaan yang positif dari perubahan dan memiliki hubungan yang aman; kemampuan untuk mengontrol dan pengaruh spiritual (Connor, 2003). Pada tahun 2013 skala CD-RISC dimodifikasi dan ditambah 2 aitem menjadi 27 aitem. Skala CD-RISC yang telah dimodifikasi dapat digunakan dalam mengukur peningkatan resiliensi pasien kejiwaan seperti mereka yang menghadapi penyakit seperti PTSD, depresi dan kecemasan. Jenis peralatan instrumen ini adalah refleksi dari model biopsikologi untuk pengobatan yang telah ditetapkan oleh penyakit kejiwaan dan dimungkinkan diperkuat oleh dukungan sosial dan tujuan (goa/s). Keduanya adalah komponen penting 
dalam terapi (Dong, 2013).

Berdasarkan analisis faktor diperoleh empat faktor pembentuk resiliensi individu, yaitu fleksibilitas untuk mengatasi perubahan dan tantangan, dukungan dari keluarga dan lingkungan sosial, pengaruh spiritual dan memiliki kehidupan yang berorientasi pada tujuan. Fleksibilitas untuk mengatasi perubahan dan tantangan merupakan kemampuan penyesuaian membantu individu untuk menyusun tujuan jangka panjang terhadap situasi sulit yang akan atau sedang dihadapi. Kemampuan ini membentuk individu tidak cepat menyerah dan senantiasa memiliki jalan keluar dalam situasi sulit. Sedangkan dukungan dari keluarga dan lingkungan sosial membuat individu memiliki dukungan psikologis untuk menghadapi situasi sulit dan tertekan. Lebih lanjut pengaruh spiritual merupakan keyakinan spiritual yang penting untuk membentuk individu menjadi pribadi yang memiliki resiliensi. Keyakinan yang didasarkan pada aspek spiritual akan menyadarkan individu untuk tidak menyalahkan diri sendiri dan orang lain saat menghadapi situasi yang tertekan. Faktor terakhir memiliki kehidupan yang berorientasi pada tujuan, dengan tujuan hidup yang jelas membantu individu tetap berpikir dan bertindak positif meskipun saat ini sedang menghadapi situasti yang sulit.

Penelitian ini bertujuan untuk menguji validitas konstruk skala Connor-Davidson Resilience Scale (CD-RISC) pada populasi orang Indonesia dewasa dengan analisis faktor konfirmatori. Informasi validitas konstruk sangat diperlukan sebagai dasar penggunaan skala CD-RISC untuk mengukur resiliensi pada orang Indonesia.

\section{Metode}

Sampel penelitian sebanyak 109 orang yang berjenis kelamin laki-laki dan perempuan, secara berurutan $33 \%$ dan $67 \%$. Rentang usia subjek antara 18 sampai dengan 40 tahun, yang termasuk dalam rentang usia dewasa awal (Hurlock, 1980). Responden memiliki pekerjaan yang beragam, mulai dari ibu rumah tangga sampai karyawan BUMN.

\section{Tabel 1. Sebaran aitem skala CD-RISC}

\begin{tabular}{lcc}
\hline \multicolumn{1}{c}{ Faktor } & Sebaran aitem & Jumlah \\
\hline $\begin{array}{l}\text { Fleksibilitas untuk mengatasi perubahan dan } \\
\text { tantangan }\end{array}$ & $1,4,5,6,8,12,14,16,18,19$ & 10 \\
Dukungan dari keluarga dan lingkungan-sosial & $2,7,24$ & 3 \\
$\begin{array}{l}\text { Pengaruh spiritual, yakin kepada Tuhan } \\
\begin{array}{l}\text { Memiliki kehidupan yang berorientasi pada } \\
\text { tujuan }\end{array}\end{array}$ & $3,9,13$ & 3 \\
\hline
\end{tabular}

Alat ukur yang digunakan adalah skala CD-RISC yang sudah diadaptasi Bahasa Indonesia oleh Kurniawan (2015). CD-RISC memiliki 4 faktor dengan 25 aitem yang semuanya favorable. Tabel 1 menggambarkan rincian penyebaran aitem skala CD-RISC.

Setelah mendapatkan izin, peneliti kemudian membuat google form untuk pengumpulan data. Peneliti melakukan analisis terhadap data yang terkumpul dengan menggunakan Confirmatory Factor Analysis (CFA) melalui program AMOS 24. Tabel 2 menunjukkan kriteria fit indeks dan batasan penerimaan dalam analisis faktor konfirmatori (Hair, Black, Babin, \& Anderson, 2010; Hu \& Bentler, 1999; Tabachnick \& Fidell, 2013). 
Tabel 2. Fit indeks

\begin{tabular}{ll}
\hline \multicolumn{1}{c}{ Index } & $\begin{array}{c}\text { Batas } \\
\text { penerimaan }\end{array}$ \\
\hline Taraf signifikansi chi-square $(\mathrm{p})$ & $>0,05$ \\
TLI & $>0,95$ \\
$\mathrm{CFI}$ & $>0,95$ \\
RMSEA & $<0,06$ \\
\hline
\end{tabular}

Hasil

Model yang peneliti analisis adalah model recursive (tidak ada hubungan regresi resiprokal antar variable laten) dengan jumlah sampel 109. Dilihat dari kriteria goodnessfit model telah memenuhi kriteria fit. Tabel 3 menunjukkan nilai chi-square 277,534 dengan probabilitas 0,70 . Nilai TLI $(0,959)$ dan CFI $(0,967)$ di atas batas penerimaan. Selain itu diperoleh nilai RMSEA di bawah 0,08 yaitu 0,036 .

Tabel 3.Nilai CMIN

\begin{tabular}{lrrrrr|}
\hline Model & NPAR & CMIN & DF & P & CMIN/DF \\
\hline Default model & 81 & 277,354 & 244 &, 070 & 1,137 \\
Saturated model & 325 &, 000 & 0 & & \\
Independence model & 25 & 1298,020 & 300 &, 000 & 4,327 \\
\hline
\end{tabular}

Tabel 4. Nilai Standardized Regression Weights

\begin{tabular}{ll}
\hline Item & Loading factor \\
\hline Item $18 \leftarrow$ fleksibilitas & 0,964 \\
Item $16 \leftarrow$ fleksibilitas & 0,811 \\
Item $19 \leftarrow$ fleksibilitas & 0,704 \\
Item $14 \leftarrow$ fleksibilitas & 0,627 \\
Item $8 \leftarrow$ fleksibilitas & 0,601 \\
Item $12 \leftarrow$ fleksibilitas & 0,569 \\
Item $24 \leftarrow$ dukungan & 0,440 \\
Item $2 \leftarrow$ dukungan & 0,400 \\
Item $\leftarrow$ dukungan & 0,219 \\
Item $13 \leftarrow$ spiritual & 0,703 \\
Item $9 \leftarrow$ spiritual & 0,489 \\
Item $3 \leftarrow$ spiritual & 0,483 \\
Item $22 \leftarrow$ orientasi & 0,897 \\
Item $21 \leftarrow$ orientasi & 0,740 \\
Item $17 \leftarrow$ orientasi & 0,612 \\
Item10 $\leftarrow$ orientasi & 0,601 \\
Item $20 \leftarrow$ orientasi & 0,596 \\
Item $25 \leftarrow$ orientasi & 0,574 \\
Item $11 \leftarrow$ orientasi & 0,571 \\
Item $25 \leftarrow$ orientasi & 0,547 \\
Item $23 \leftarrow$ orientasi & 0,318 \\
\hline
\end{tabular}

Dari Tabel 4 tampak bahwa faktor satu yaitu fleksibilitas yang dijabarkan menjadi 10 aitem, memiliki standardized loading factor bergerak dari 0,345 sampai 0,964. Pada faktor kedua yaitu dukungan yang terdiri dari tiga aitem memiliki standardized loading factor bergerak dari 0,219 sampai dengan 0,440 . Selanjutnya pada faktor ketiga yaitu spiritual memiliki standardized loading factor bergerak dari 0,483 sampai dengan 0,703. Pada faktor terakhir yaitu orientasi tujuan memiliki standardized loading factor bergerak dari 0,318 sampai dengan 0,897 .

\section{Gambar 1. Pemodelan Konstruk Resiliensi}

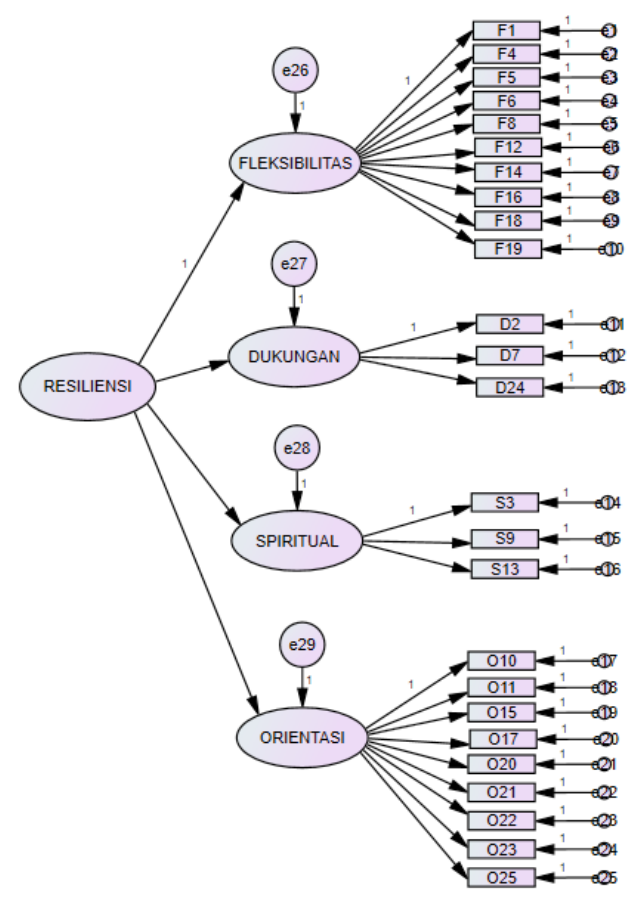


Dalam analisis faktor konfirmatori, presentasi rata-rata nilai variance extracted antar item atau indikator suatu set konstruk laten merupakan ringkasan convergen indicator. Tabel 5 juga menunjukkan nilai average variance extracted (AVE), nilai reliabilitas dari masing-masing konstruk laten dan nilai discriminant validity.

Tabel 5. Nilai AVE

\begin{tabular}{llll}
\hline $\begin{array}{l}\text { Konstruk } \\
\text { laten }\end{array}$ & $\begin{array}{l}\text { Nilai } \\
\text { AVE }\end{array}$ & Reliabilitas & $\begin{array}{l}\text { Nilai } \\
\text { DV }\end{array}$ \\
\hline Fleksibilitas & 0,449 & 0,883 & 0,670 \\
Dukungan & 1,200 & 0,301 & 1,095 \\
Spiritual & 0,322 & 0,579 & 0,567 \\
Orientasi & 0,391 & 0,844 & 0,625 \\
\hline
\end{tabular}

Tabel 5 menunjukkan bahwa konstruk dukungan memenuhi kriteria AVE, yaitu di atas 0,50 , sedangkan tiga aspek lainnya tidak memenuhi kriteria AVE. Tabel 5 juga menunjukkan bahwa konstruk laten yang memiliki reliabilitas yang tertinggi adalah kontruk fleksibilitas dan diikuti konstruk orientasi. Kedua konstruk ini memiliki reliabilitas yang tinggi karena berada di atas 0,70 , sedangkan konstruk dukungan dan spiritual mempunyai nilai reliabilitas dibawah 0,70 . Berdasar data pada Tabel 5, dalam permodelan ini konstruk laten yang memiliki nilai diskriminan paling tinggi adalah konstruk dukungan. Ketiga konstruk lainnya memiliki nilai diskriminan kurang dari 0,70.

\section{Pembahasan}

Berdasarkan hasil analisis data dengan analisis faktor konfirmatori menunjukkan bahwa konstruk resiliensi yang diukur dengan CD-RISC fit. Hal tersebut ditunjukkan dengan salah satunya hasil chi-square yang tidak signifikan secara statistik, yang mengindikasikan model empiris sesuai dengan model teoritis. Model dikatakan baik apabila menolak secara statistic (Ghozali, 2011). Nilai probabilitas yang baik adalah di atas 0,05 , dan pada model ini nilai probabilitas yaitu mencapai 0,07 .
Salah satu manfaat dari CFA adalah kemampuan menilai konstruk dari measurement theory yang diusulkan. Validitas konstruk mengukur sampai seberapa jauh indikator mampu merefleksikan kontruk laten teoritisnya. Jadi validitas konstruk memberikan kepercayaan bahwa ukuran indikator yang diambil dari sampel menggambarkan skor yang sesungguhnya di dalam populasi. Terdapat empat ukuran validitas konstruk yaitu convergent validity, average variance extracted (AVE) , reliability dan discriminant validity (DV).

Dari ukuran convergent validity terdapat delapan aitem yang mempunyai nilai loading factor kurang dari 0,50 yang berasal dari keempat faktor. Uji convergent validity mensyaratkan loading factor minimal sebesar 0,5 (Hair dkk, 2010). Pada faktor fleksibilitas dua aitem yang memiliki loading factor lebih kecil dari pada 0,5 adalah aitem nomor 5 dan 6. Sedangkan dari faktor dukungan, ketiga aitem semuanya memiliki loading factor lebih kecil daripada 0,5. Dua aitem pada faktor ketiga spiritual memiliki loading factor di bawah 0,5 yaitu nomor 3 dan 9 . Hanya satu aitem yaitu nomor 23 pada faktor keempat orientasi tujuan yang memiliki loading factor lebih kecil daripada 0,5 . Temuan ini menunjukkan bahwa ke delapan aitem perlu diperbaiki agar dapat memenuhi kriteria convergent validity.

Berdasarkan average variance extracted, hanya satu faktor dari keempat faktor resiliensi yang memenuhi syarat. Konstruk laten dukungan memenuhi kriteria AVE yaitu $>0,50$. Sedangkan konstruk laten fleksibilitas, spiritual dan orientasi memiliki nilai AVE $<0,50$.

Dari sisi reliabilitas, persyaratan reliabilitas minimal suatu konstruk adalah 0,70. Konstruk laten yang memiliki reliabilitas yang tinggi adalah kontruk fleksibilitas dan orientasi karena berada di atas 0,70 (yang disyaratkan baik). Sedangkan konstruk dukungan dan spiritual mempunyai nilai reliabilitas di bawah 0,70 (yang dipersyaratkan).

Discriminant validity mengukur sampai seberapa jauh suatu konstruk benar- 
benar berbeda dari konstruk lainnya. Nilai discriminant validity yang tinggi memberikan bukti bahwa suatu konstruk adalah unik dan mampu menangkap fenomena yang diukur. Dalam permodelan ini konstruk laten yang memenuhi nilai diskriminan paling tinggi adalah konstruk dukungan karena melebih 0,70 dan ketiga konstruk lainnya tidak memenuhi karena kurang memenuhi 0,70.

Keterbatasan penelitian ini terletak pada jumlah responden. Meskipun jumlah responden telah memenuhi jumlah minimal untuk dilakukan analisis faktor konfirmatori yaitu 100 orang (Hair et al., 2010), namun Mundfrom, Shaw, and Ke (2005) berpendapat bahwa ukuran sampel kecil dalam melakukan fackor analisis akan dipengaruhi oleh tingkat komunalitas yang mengindikasikan jumlah varians dan jumlah variable yang akan diukur dalam masing-masing faktor. Oleh karenanya penelitian selanjutnya dapat melibatkan responden dealam jumlah yang lebih besar dan memperbaiki ke delapan aitem yang memiliki loading factor di bawah 0,5

\section{Kesimpulan}

Hasil penelitian menunjukkan bahwa semua faktor dari modifikasi skala CD-RISC yaitu: fleksibilitas untuk mengatasi perubahan dan tantangan, dukungan dari keluarga dan lingkungan sosial, pengaruh spiritual dan memiliki kehidupan yang berorientasi pada tujuan memerlukan modifikasi untuk mencapai model fit. Setelah melakukan analisis faktor konfirmatori terhadap empat faktor dari resiliensi bahwa modifikasi skala CD-RISC

dapat menjadi pertimbangan untuk mengukur resiliensi

\section{Ucapan Terima Kasih}

Peneliti mengucapkan terima kasih kepada Direktorat Riset dan Pengabdian Masyarakat Deputi Bidang Penguatan Riset dan
Pengembangan Kementerian Riset dan Teknologi / Badan Riset dan Inovasi Nasional yang telah mendanai penelitian ini dengan skema hibah Penelitian Tesis Mahasiswa (Kontrak Nomor: PTM-029/SKPP.TT/LPPM UAD/VI/2020)

\section{Daftar Pustaka}

Connor, K. M. (2003). Development of a new resilience scale: the connor-davidson resilience scale (CD-RISC). Depression and anxiety 18(2), 76-82.

Dong, F. N.-H. (2013). A Modified CD-RISC: Including previously unaccpunted resilience variables. Kansas Journal of Medicine, 11-20.

Feist, J. F. (2009). Theories of Personality. New York: McGraw-Hill.

Garcia-Dia, M. D. (2013). Concept analysis: Resilience. Archives of Psychiatric Nursing 27, 264-270.

Ghozali, I. (2011). Model persamaan struktural konsep dan aplikasi dengan program amos 24. Semarang: Badan Penerbit Undip.

Hair, J. F., Black, W., Babin, B. J., \& Anderson, R. E. (2010). Multivariate data analysis: A global perspective (Seventh ed.). New Jersey: Pearson Prentice Hall.

Hendriani, W. (2018). Resiliensi psikologis. Jakarta: Prenadamedia Group.

Hu, L. T., \& Bentler, P. M. (1999). Cutoff criteria for fit indexes in covariance structure analysis: Conventional criteria versus new alternatives. Structural Equation Modeling-a Multidisciplinary Journal, 6(1), 1-55.

Lesmana, J. M. (2008). Dasar-dasar konseling. Jakarta: UI Press.

Meichenbaum, D. (2009). Bolstering resilience: Benefiting from lesson learned in D. Brom, R Pat-Horenczyk \& J.D. Ford 
(Eds). New York: Routledge.

Mundfrom, D. J., Shaw, D. G., \& Ke, T. Lu. (2005). Minimum sample size recommendations for conducting factor analyses. International Journal of Testing, 5(2), 159-168.

Rainey, E. E. (2014). Psychological factors predicting outcome after traumatic injured: the role of resilience. The American Journal of Surgery 208(4), 517-523.

Santrock. J., W. (2012). Life-Span Development . Jakarta.

Tabachnick, B. G., \& Fidell, L. S. (2013). Using multivariate statistic (Sixth ed.). New Jersey: Pearson Education, Inc.

Tashiro, T. \&. (2003). "I'll never be in a relationship like that again": Personal growth following romantic relationship breaksup. Personal relationship 10(1), 113-128.

Utami. C., T. \&. (2017). Self-Efficacy dan Resiliensi Sebuah Tinjauan MetaAnalisis. Buletin Psikologi 25(1), 54-65. 